\title{
Francis Crozier (1796-1848?)
}

It is possible that John Franklin died a happy man on 11 June 1847. H.M. ships Erebus and Terror had been beset off King William Island since 12 September 1846 , but some of his men had travelled to the southwestern part of the island, and they may have returned to the ships in time to report to the dying captain that a Northwest Passage did in fact exist and that they were very close to negotiating it. But the icy grip was not released that summer or autumn, and twenty officers and men died by the end of the following winter. On 22 April 1848, the Erebus and Terror were abandoned and Captains Francis Crozier and James Fitzjames led the survivors down the west coast of King William Island in a desperate bid to reach the North American mainland. The rest is tragic history. Crozier's "failure", if indeed the failure is his, must be understood in the light of his past successes: because he was not inexperienced in polar matters, the reasons for the Franklin tragedy are even more mysterious and perplexing.

Francis Rawdon Moira Crozier was born in September, 1796, at Banbridge, Ireland. He entered the Navy on 12 June 1810 as a First-class Volunteer on board the Hamadryad and was then removed, in June 1812, as midshipman to the Briton, ordered to Valparaiso to arrest the U.S. frigate Essex, which was interfering with British whale fisheries. On its return voyage, the Briton became the second ship, after the Topaz, an American sealing vessel, to visit Pitcairn Island. At that time, only one of the original Bounty mutineers, John Adams, was alive. On his return to England, Crozier spent nearly two years on the Thames guardship Meander and the Portsmouth flagship Queen Charlotte. In 1818 he was appointed Mate to the Doterel.

Crozier then accompanied W. Edward Parry in two successive expeditions in search of a Northwest Passage, in 1821 and again in 1824. An important member of both expeditions was James Clark Ross; and in the years to come, the destinies of Crozier and Ross would become inextricably, and sometimes ironically, linked. The first expedition spent two winters in the Arctic, and during the second, which was particularly severe, one of Crozier's duties was to transport invalided Eskimos to the Fury and Hecla sick bays. What did he learn, or fail to learn, of Eskimo survival strategy during this time? During the second expedition, the Fury was wrecked and unloaded at Fury Point on the west side of Prince Regent Inlet. If Crozier had led his men to these stores in the spring of 1848 , it is possible that some members of the Franklin expedition might have survived, for the stores were intact and his good friend and would-be rescuer, James Ross, was on his way to that area in the summer of 1848 .

On 2 March 1826, Crozier received his lieutenant's commission and rejoined Hecla under Captain Parry. Crozier watched over the ship anchored in Treurenburg Bay, Spitsbergen, while Parry, James Ross, and two others attempted to reach the North Pole over ice. The inventive and enterprising
Parry even tried to use reindeer to pull the sledges. Though they failed in their main objecctive, the men travelled farther north than any white men had previously.

In April 1831, Crozier was appointed to the Stag, stationed off the coasts of Spain and Portugal. In December 1835, he was appointed first lieutenant and second-in-command to James Ross, HMS Cove, which was sent on a humanitarian mission to bring relief to 11 whaling ships beset in Davis Strait.

Between 1839 and 1841, James Ross and Francis Crozier commanded three highly successful expeditions in the Antarctic. Their ships were the very same ones that were used in the last Franklin expedition, the Erebus and Terror, and a legacy of their passage may be traced upon maps of the Antarctic in the naming of Mount Erebus, Mount Terror, Ross Ice Shelf, and Cape Crozier. Winter quarters were at Hobart, Tasmania (then called Van Diemen's Land), where Sir John Franklin was Lieutenant-Governor. At Hobart, Crozier fell hopelessly in love with Sir John Franklin's niece, Sophia Cracroft, whereas she, in turn, seemed infatuated with James Ross, who was already engaged. Although she refused Crozier's marriage proposal, made, it is speculated, just before he left for the Arctic for the last time, Sophia Cracroft spent the rest of her life singlemindedly helping Lady Franklin pressure the British government to try to determine the exact fate of the lost expedition.

On 30 May 1830, 18 years before the tragedy, James Ross stood at Point Victory on the northeastern corner of King William Island and described the great masses of pack ice coming down McClintock Channel - ice that would later entrap the Erebus and Terror and his friends and fellow explorers, Franklin and Crozier - as "the heaviest masses I have ever seen...." If Ross, the discoverer of King William "Land", had recognized that it was really an island, and not connected to Boothia, then the Erebus and Terror might have sailed to the east of that island and successfully negotiated the Northwest Passage. The ironies multiply indefinitely.

\section{FURTHER READINGS}

COOPER, PAUL FENIMORE. 1961. Island of the Lost. New York: G.P. Putnam's Sons.

CYRIAX, R.J. 1939. Sir John Franklin's Last Arctic Expedition. London: Methuen.

FLUHMANN, MAY. 1976. Second in Command: A Biography of Captain Francis Crozier, R.N., F.R.S., F.R.A.S. Yellowknife: Government of the Northwest Territories.

ROSS, JAMES CLARK. 1969. A Voyage of Discovery and Research In The Southern And Antarctic Regions, 1839-43. New York: Augustus M. Kelley.

Geraldine Rahmani

402 - 528 25th Ave. S.W.

Calgary, Alberta, Canada

T2S 0L5 


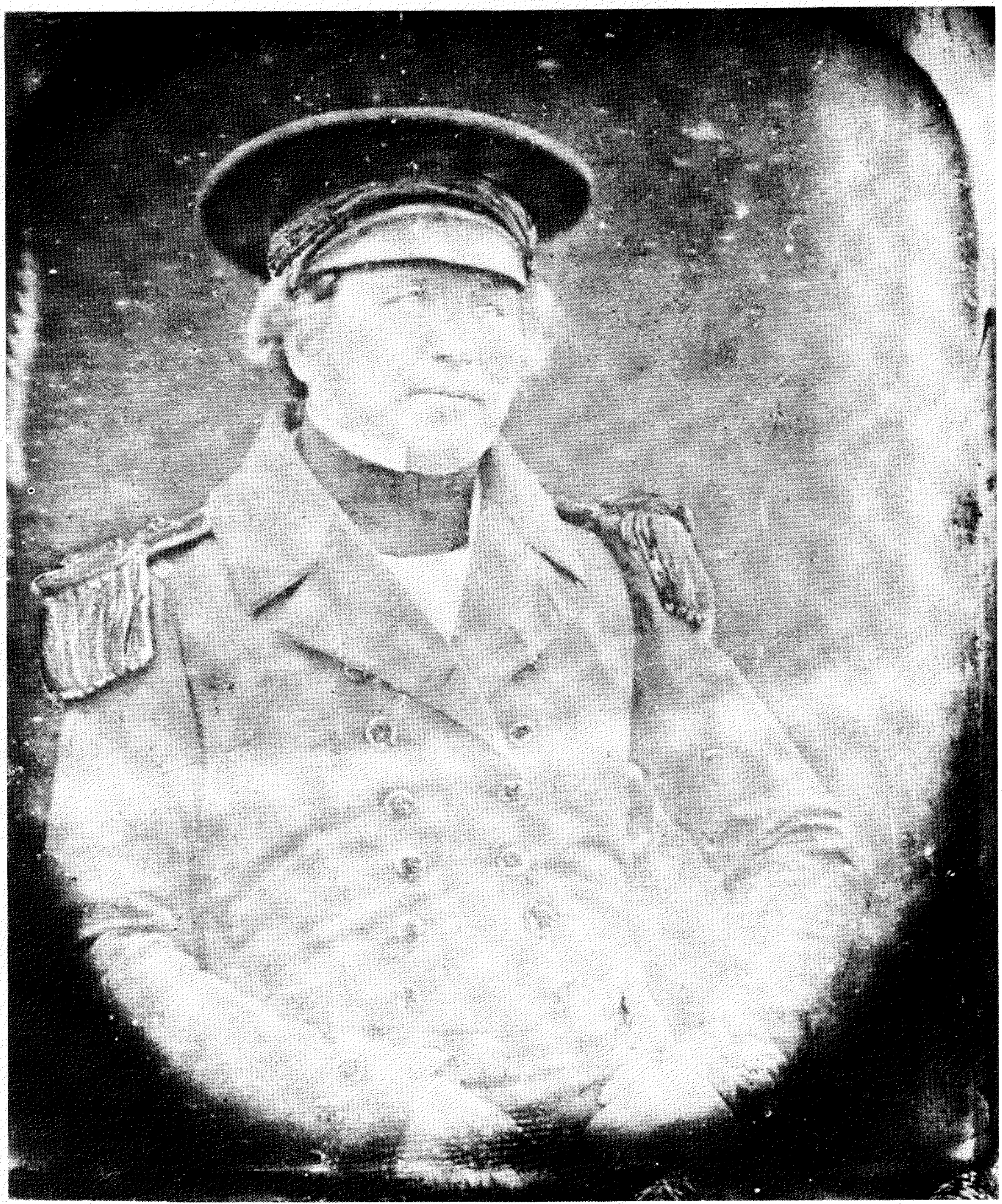

Photograph courtesy of National Maritime Museum, Greenwich. 